\title{
Environtmental Conservation Based on Local Wisdoms in Kendal Ngisor, Banyubiru
}

\author{
Wahyu Setyaningsih ${ }^{1}$, Erni Suharini ${ }^{2}$, Yuliawati $^{3}$ \\ \{wahyusetyaningsih@mail.unnes.ac.id ${ }^{1}$, ernisuharini@gmail.com ${ }^{2}$, yuliawati516@gmail.com ${ }^{3}$ \} \\ ${ }^{1,2}$ Universitas Negeri Semarang, Indonesia \\ ${ }^{3}$ MA Hidayatullah, Pringsurat, Temanggung, Indonesia
}

\begin{abstract}
The community in Kendal Ngisor, Wirogomo Village develops environmental conservation activities through local wisdoms that have been going on for generations. The local wisdoms in Kendal Ngisor play a role in preserving environmental sustainability, even in certain cases they include myths, rituals and good advice that are capable of governing the community in such a way as to the environment. The objectives of this research are to study the forms of local wisdom and their influence in preserving the environment sustainability in Kendal Ngisor. This research uses qualitative approach with triangulation data analysis techniques. The results of this research indicate that the community of Kendal Ngisor develops several local wisdoms in the forms of nyadran kali, nyadran gunung, and sedekah bumi. The inheritance of local wisdom in the area is done through informal education. Nyadran Kali is the community's effort to maintain the quality and quantity of springs through clean sources and protection of green areas around the springs. Nyadran Gunung plays a role in maintaining the ecological function of the Kelir mountain and Sedekah Bumi is an expression of gratitude for the abundant harvest through traditional activities.
\end{abstract}

Keywords: Local Wisdom, Preserving Environmental Sustainability, Nyadran.

\section{Introduction}

A local wisdom is a cultural knowledge acquired by a certain community involving an amount cultural knowledge related with the models of sustainable use and management of natural resources [1]. The forms of local wisdom that can be found in the community are values, norms, beliefs, and special rules that apply in the community [2]. Kendal Ngisor village, Banyubiru subdistrict, Semarang regency has local wisdoms that are still maintained today. The wisdoms are closely related to the community's environmental preservation and early efforts to prevent landslides from occurring for generations.

Landslide disasters in the Kendal Ngisor village occured in the slopes of Mount Kelir in 2015 and in early 2016. This disaster caused a fatality and a damage to arable lands and the roads to the community lands [3]. According to the Semarang Regency Public Works Agency (DPU), the 
landslides that occurred in this area were because the geological structure in the Kendal Ngisor village is in the form of a fracture structure located on andesite rocks. Therefore, this large amount of fracture structure causes the rocks to be fragile [4]. Since the landslide, the community change the farming time, for instance they do not grow crops during the rainy season and stop working in the afternoon or earlier than they did before the disaster occurred.

The interrelation of the local wisdoms in the environment preservation efforts in Kendal Ngisor village is focused on the interests of the local communities because the integrity of conservation areas cannot be maintained without providing life sources for the locals whose survival depends heavily on the natural resources in their area [5].

The local wisdoms in Kendal Ngisor in Wirogomo village, Banyubiru subdistrict, can still survive to this day so that they can become some of the efforts to preserve the environment and prevent disasters in the region [6]. This study aims to identify the variety of the local wisdoms that develop in the community of Kendal Ngisor village and identify the ability of the community to convey information and pass on the local wisdoms through informal education in the family and through traditional activities.

\section{Research Methods}

The study makes use of a qualitative method, a triangulated data collecting technique, inductive/ qualitative data analysis, and qualitative research data which emphasize more on meaning than on generalization. The study was carried out in Kendal Ngisor hamlet of Wirogono village in Banyubiru subdistrict. The study focuses on figuring out the forms and the influence of the local wisdoms of the village in preserving the environment. The study makes use of a triangulated data collecting technique using structured observation, structured interview, and documentation.

This study was conducted for three months by observing the local wisdom of the people in the Kendal Ngisor hamlet. informants in this study were 25 people consisting of community leaders (village heads, hamlet heads, village officials and village elders) and also the Kendal hamlet community.

\section{The Results and Discussions}

Most of Kendal Ngisor areas are on the slope of Kelir mount having a slope tilt of $30^{\circ}-50^{\circ}$ casuing rough reliefs. The mountainous landscape is utilized by the people for moors and rice fields. The agricultural activities are mostly carried out by men but women also participate in agricultural activities by doing intercropping like planting vegetables such as watercress, beans, mustard greens, and chillies, harvesting them, selling them to the market, and processing palm juice into palm sugar [7]. The community cultivates in the rice fields using an irrigation water system, because there is an abundant availability of water and the irrigation water system is able to irrigate 10 hectares of rice fields [8] . 


\subsection{The Local Wisdom Which Develops in Kendel Ngisor Hamlet}

The human-nature relationship in Kendal Ngisor hamlet can be seen in the local wisdoms which still survives to this day, namely Nyadran Kali, Nyadaran Gunung, and Sedekah Bumi. All of them have different functions and purposes but they are intersupporting.

\section{Nyadran Kali}

Nyadran Kali local wisdom is one of the people's efforts in Kendal Ngisor hamlet to preserve the water resources in four main springs in the hamlet, like Pecak, Petung, Puthek, and Dusun springs.

Pecak spring is located more or less 500 meters to the west of the hamlet. Next to the spring grows a banyan tree which is $150 \mathrm{~cm}$ in diameter. The tree is assumed to have grown there for tens of years. The spring plays an important role in supplying the water considering that the spring's area is a catchment area. The water from the spring is collected in a reservoir which is later distributed to the fields through the irrigation system. The spring is always available regardless the seasons, so during the dry season the water can still be used to irrigate the fields.

Petung spring is located between Kendal Ngisor and Kendal Dhuwur hamlets and it is also utilized to irrigate rice fields. To the west side of the halmet is Puthek spring which is collected and distributed to people's houses for cooking and bathing. Dusun spring which is located in Kendal Ngisor hamlet is utilized for public bathing facility. Around the spring, people build a pool to collect water and the water is distributed through pipes. 


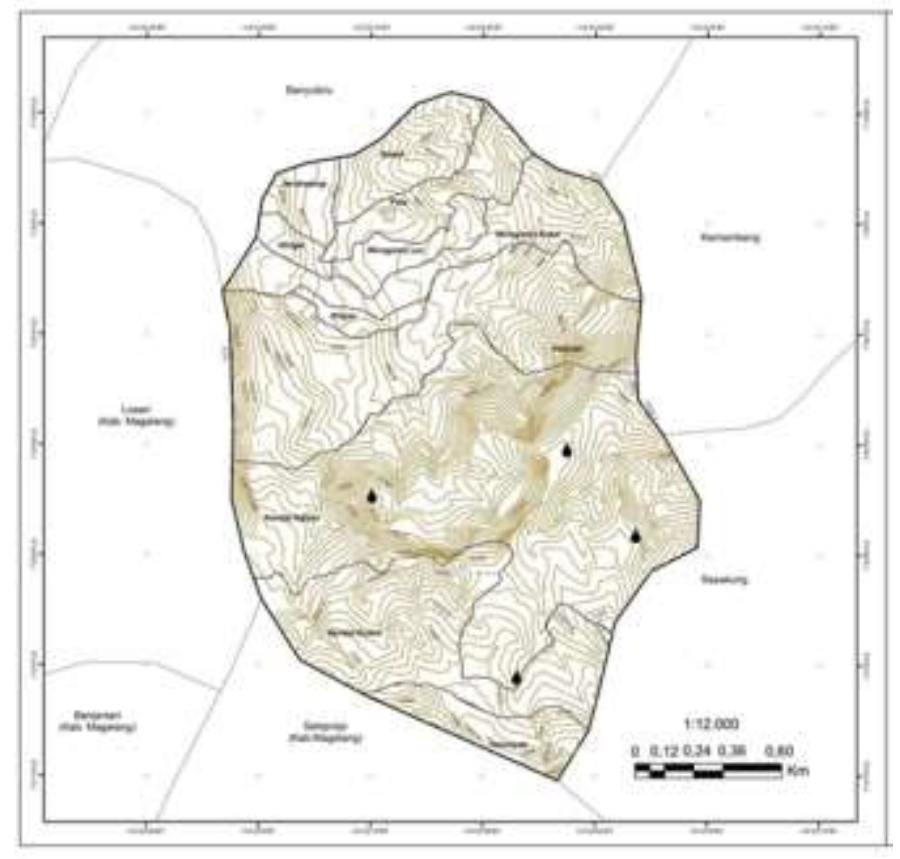

Fig 1. The Springs in Kendal Ngisor hamlet

Nyadran Kali in Kendal Ngisor consists of two nyadrans, namely nyadran for agriculture and nyadran for the ancestors. Nyadran Kali for agriculture is carried out to give thanks to God and pray for the blessing of water for the irrigation, while Nyadran Kali for the ancestors is carried out to give thanks to God and pray that the water will always be available for the people to consume. Nyadran Kali is carried out in ba'dha maulud month (based on the Hijri calendar) on the fourth week Friday (on Friday pon or kliwon).

Nyadran Kali begins in the morning by planting trees to replace the dead or damaged ones on the slope of Kelir mount and checking the condition of other trees around the spring. Other activities are cleaning up the environment surrounding the spring, repairing the water reservoir and pipes, and cleaning the access road to the spring. To maintain the water quality, people living in Kendal Ngisor prohibit cutting down trees on Kelir mount for years and prohibit agricultural activities on some parts of the mountain slope in order to prevent agricultural waste pollution to the spring water. 


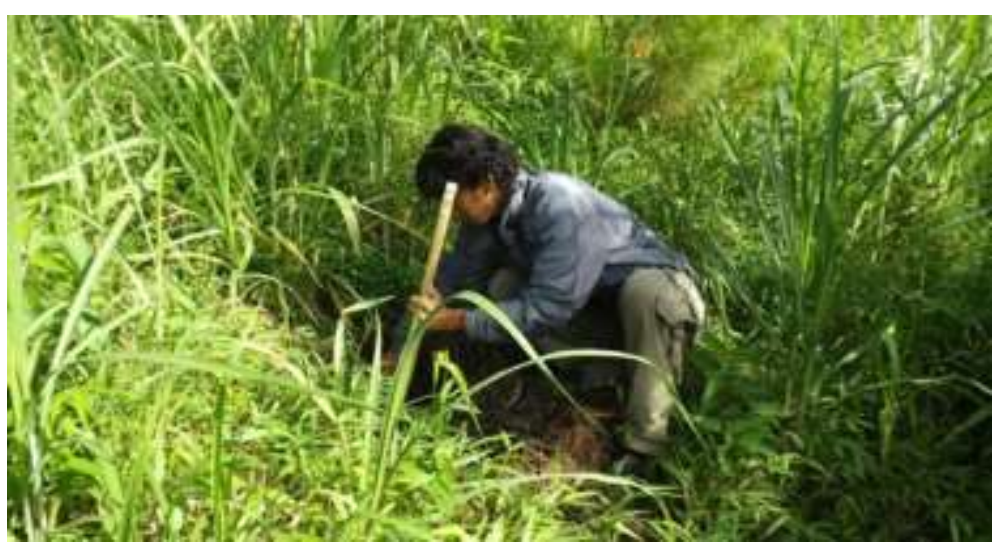

Fig 2. Planting trees around Dusun spring

After cleaning up the environment surrounding the spring, the male villagers perform a ceremony to give thanks to God in the spring area. In the evening afterwards, they perform Nyadran Kali Leluhur in the house of the head of village. All male villagers carry tumpeng rice that will later be eaten together after the prayer. The thanksgiving procession symbolizes the villager's gratitude for the blessings of pristine spring water, and it is also a form of prayer to God for future blessings.

\section{Nyadran Gunung}

Nyadran gunung is carried out after performing nyadran kali. It is carried out on the last week of Safar mount (based on the Hijri calendar). Its purpose is to retain the ecological functios of the mountain slope. Nyadran gunung procession begins by planting trees on mount Kelir, cleaning up and repairing the road heading to the slope of the mountain as an access road for the villagers to go to their fields. The road is 1250 meters away from the people's settlement. After the cleaning up, the male villagers bring tumpeng rice along with the side dishes to the slope of the mountain for mass prayers. At the end of the procession, they bring home the rice they have brought to be eaten with their family members. 


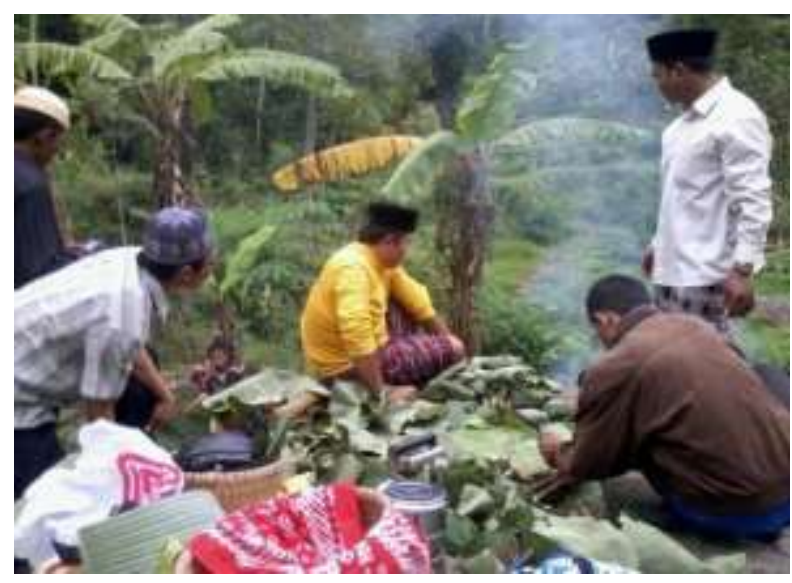

Fig 3. Nyadran Gunung procession in the mountain slope

This local wisdom of Nyadran Gunung is an effort to retain the ecological functions of the slope as a catchment area and to preserve the vegetation to prevent landslides. The slope of mount Kelir as a water catchment area is protected by the Forest Service which is divided into protected areas and areas that can be utilized by the people as moors. The slopes of mount Kelir are planted with various types of trees that can strengthen the soil. The plants are those with strong roots so that they can prevent the soil from breaking down into a landslide. The slopes of mount Kelir as a place for people's activities can be used to fulfill their daily needs, for example they plant palm trees that produce sap which can be processed into brown sugar which later will be sold and then the money is used to meet their daily needs. Another example is they harvest taro for sale and consumption. Therefore, with this cycle, they feel the necessity to perform nyadran gunung as an expression of gratitude to God Almighty.

The people living there know that the mountain slope is very beneficial for their lives since it provides sufficient water, the sustainability of crop production through sustained soil fertility, and the safe protection functions for the surrounding ecosystems. Nyadran gunung ceremony cannot be changed either in the procedure of its implementation or its purpose, as stated by Mr. Sardi as follows.

Kendal Ngisor people realize that humans co-exist with the nature so they must preserve the natural balance by performing a preserved tradition of nyadran gunung. Nyadran gunug is carried out to preserve the slopes with vegetation. The vegetation on the slopes of mount Kelir serves to protect the soil and control water for life. Therefore, maintaining the ecological function of the slope will result to firm soil because the plants will prevent the rainwater from immediately falling to the surface of the soil. Moreover, the fallen leaves will form topsoil that is able to absorb water well. Thus, the protected land can regulate the water in order that it will not be excessive in the rainy season and will not run dry in the dry season. 


\section{Sedekah Bumi}

Sedekah bumi is one of the geographical patterns that causes phenomena or events on the surface of the earth both naturally and socially. This event is held at the end of Safar month or if there is a Friday pon in the last week of the month. However, if there is no Friday pon, the event will be held in Ba'dha Maulud. The ceremony is carried out once in two years. This is adjusted with the economic condition of the people.

The ways people express their gratitude for the blessings from God Almighty are not only shown through the ceremonies of nyadran gunung and nyadran kali, but they also carry out sedekah bumi. This ceremony is one form of local wisdoms as an expression of gratitude to God who has provided a source of life in the form of crops and water.

According to a source (Margono), sedekah bumi serves as a form of gratitude for the blessings of God Almighty has provided, so they can benefit from the crops. People believe that if they are always grateful, they will get abundant crops. The rice farming in the village relies on irrigation water and on the use of compost to support crop yields. The agriculture system that develops in Kendal Ngisor are a farming system of rice fields and farms. The people utilize the slopes as fields to plant corn, tubers, and they plant vegetables such as beans, hates, mustard greens and chili on the fields.

The people apply the Javanese calendar (pranoto mongso) in carrying out agriculture activities. The system provides directions to farmers when to grow crops following the natural signs of the season, not utilizing land as they wish even though they have supporting facilities and infrastructure, for example the water and irrigation channels are regulated through the calculation of pranoto mongso to maintain natural balance.

The distribution principle which is a description of the spread of unequal natural phenomena provides advantages and disadvantages in an area, for example the wealth of natural resources in the Kendal Ngisor village. The natural resources in Kendal Ngisor include fertile land, and abundant sources of spring water. Natural resources are related to the environment where humans live because it is the space occupied by living beings along with other nonliving living beings.

The people in Kendal Ngisor live alongside with the nature, cultivating land for farming. The sedekah bumi ceremony becomes a form of gratitude in preserving the environment. The interaction with the nature should be based on the principles of environmental preservation. As stated by a source, if the natural environment is maintained then the people will easily cultivate the land so that it will be fertile and provide abundant crops so that it is used to meet needs. Consequently, if human needs are fulfilled, it will result to the physical health of the people.

The people living on the slope of mount Kelir maintain its ecological function by planting vegetation because they use it as a place for farming. Related agencies such as the Forestry and Agriculture Service provide support by providing tree seedlings and encouraging the people to keep planting vegetation.

The sedekah bumi celebration is held at night featuring reog (kuda lumping), kuntulan, and shadow puppet performances. The shadow puppet performace possesses a philosophical teaching for the community because the chosen puppet characters are farmers who work earnestly so tha they can bring home abundant crops. It also represents what people expect in the real lives, their hard work, and their high enthusiasm they apply in life. 


\subsection{The Inheritance System}

The local wisdoms develop in the community through informal education in the family environment through advice and examples of the behavior of parents to their children, as well as in the community as the values adopted by the community in the area. The values of life adopted by the community will influence the actions of the community to preserve the environment. The local wisdom of Nyadran Kali, Nyadran Gunung and Sedekah Bumi have existed for a long time and are still going on until now. Their presence can survive until now because the people have passed them down from a generation to another.

Based on the statement of the head of the Kendal Ngisor hamlet (Margono), the local wisdoms there can survive to this day because of the awareness of the community like to invite children to follow the processions of nyadran kali, nyadran gunung and sedekah bumi, thus indirectly providing knowledge to preserve the environment by observing the processions. The inheritance system is a process of education and learning from one generation to another. The local wisdoms in Kendal Ngisor hamlet originated from ancestors and are passed down through the head of hamlet.

The following is a inheritance system chart of the local wisdoms in Kendal Ngisor hamlet:

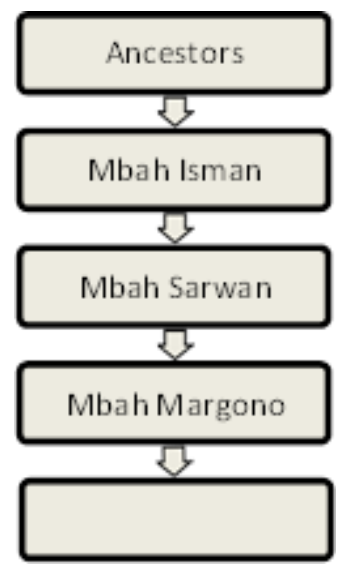

Fig 1. The Local Wisdom Inheritance System

Based on the data on the education level of the Kendal Ngisor hamlet people, mostly they finished formal education up to elementary school level, namely 93 males and 89 females. However, their have excellent efforts to preserve the environment. It can be seen by the implementation of the tradition of nyadran/ local wisdom. The local wisdoms are maintained through informal education because it is an education that takes place in a family environment and it takes place naturally and properly through examples from parents behavior in preserving the environment for generations [9]. 
The life of the Kendal Ngisor people grows through traditions, behaviors or knowledge developing according to the closeness of the people to the surrounding environment and the challenges they face are water protection and disaster vulnerability. The traditional values, attitudes and behaviors regarding with the local wisdoms in the order of the people's life form their ecological intelligence. The life of the people of Kendal Ngisor hamlet leads to the preservation of the tradition inherited through generations for example the efforts to preserve the quality and quantity of springs as well as maintain the ecological function of the slopes of Mount Kelir, which plays a role in supporting life under it as a catchment area by conducting reforestation or planting vegetation. The substance of the local wisdoms is the enactment of values that are recognized by the people and determine their behavioral patterns. Their actual actions, attitudes, and behaviors towards the environment that contain the values of ecosystem preservation are part of the ecological intelligence of the community.

\section{Conclusions}

Based on the results of the research, the people of Kendal Ngisor village still maintain local wisdoms as their efforts to preserve the environment. The local wisdoms are nyadran kali, nyadran gunung, and sedekah bumi. Nyadran kali serves as an effort to maintain the quality and quantity of spring water through the improvement of facilities at spring water sources such as water pipes and water reservoirs, and reforestation. Nyadran gunung is an effort to maintain the ecological function of the slopes of Mount Kelir. The efforts conducted are reforestation on the slopes. The local wisdom of sedekah bumi acts as an expression of gratitude to God for the abundant crops that benefit the people. In order for the local wisdoms to survive until the future, it is imperative that the people carry out efforts to pass them down more constantly not only through the informal education but also through formal activities.

\section{References}

1. Pesurnay, A. J. (2018). Local Wisdom in a New Paradigm: Applying System Theory to the Study of Local Culture in Indonesia. IOP Conference Series: Earth and Environmental Science, 175(1). doi:10.1088/1755-1315/175/1/012037

2. Purwanto, W., Suharini, E., \& Setyaningsih, W. (2018). Kearifan Lokal Masyarakat Desa Segoromulyo Kecamatan Pamotan Kabupaten Rembang Dalam Menghadapi Bencana Kekeringan. Edu Geography, 6(2), 153-161.

3. Hani'Ah, Firdaus, H. S., \& Nugraha, A. L. (2017). Analysis of Environmental Vulnerability in the Landslide Areas (Case Study: Semarang Regency). IOP Conference Series: Earth and Environmental Science, 98(1). doi:10.1088/1755-1315/98/1/012013

4. Semarang, P. K. (2016). Rencana Pembangunan Jangka Menengah Daerah (RPJMD) Tahun 2016-2021 (Vol. 0).

5. Suparmini. (2013). Mitigasi Bencana Berbasis Kearifan Lokal Masyarakat Baduy. Humaniora, 19(1). 
6. Syahputra, H. (2010). Role of Local Wisdom in Acceleration of Disaster Risk Reduction in Aceh ( Kabupaten Simeulue Case ), 99-100.

7. Hidayati, N., \& Soeprobowati, T. R. (2011). Pertanian Ramah Lingkungan di Daerah Tangkapan Air Danau Rawapening Sustainable Agriculture in Water Catchment Area of Rawapening Lake, 14, 126-130.

8. $\quad$ BPS. (2015). Kecamatan Banyubiru dalam Angka 2015.

9. Listiana, I. (2016). Pewarisan Nilai-Nilai Kearifan Lokal Dalam Konservasi Mata Air Senjoyo Pada Masyarakat Desa Tegalwaton, Kecamatan Tengaran Kabupaten Semarang, $1-96$. 